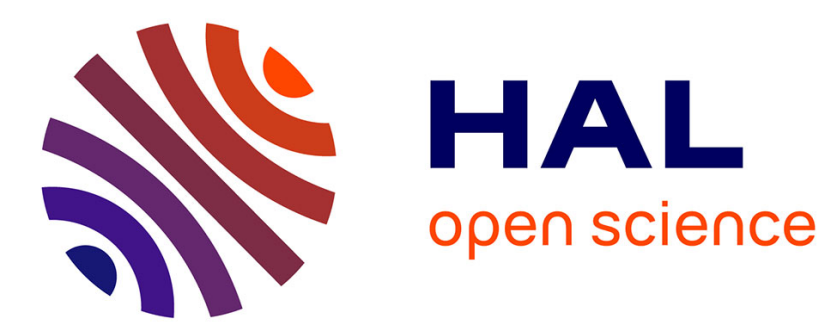

\title{
From the Migration Experience to its Visual Narration in International Mobility
}

\author{
Muriel Molinie
}

\section{To cite this version:}

Muriel Molinie. From the Migration Experience to its Visual Narration in International Mobility. Visualising Multilingual Lives. More than word, Multilingual Matters, 2019, 9781788922593. hal03320968

\section{HAL Id: hal-03320968 https://hal.science/hal-03320968}

Submitted on 16 Aug 2021

HAL is a multi-disciplinary open access archive for the deposit and dissemination of scientific research documents, whether they are published or not. The documents may come from teaching and research institutions in France or abroad, or from public or private research centers.
L'archive ouverte pluridisciplinaire HAL, est destinée au dépôt et à la diffusion de documents scientifiques de niveau recherche, publiés ou non, émanant des établissements d'enseignement et de recherche français ou étrangers, des laboratoires publics ou privés. 


\title{
Visualising Multilingual Lives. More than word
}

Edited by Paula Kalaja et DSilvia Melo-Pfeiffer

Multilingual Matters, Bristol, 2019

\section{Part one The multilingual self}

Chapter $X$

\section{From the Migration Experience to its Visual Narration in} International Mobility (pages 73- 94)

\section{MURIEL MOLINIE, EA 2288 DILTEC}

\begin{abstract}
These chapter introduces a way for international students studyinh in universities in France to reflect on their lives and envision their future in termes of social mobility. With this in mind, they were instructed to produce a drawing describing their background and visualising their mobility in the years to come in Europe or beyond. The process of viusual narratives allows individuals to describe and confront not only objective conditions but also their feelings and subjective points of view of their past, present and future (im)mobilities. This allows them to access and undestanding of international mobility as a contemporaray experience, this understanding being both objective and subjective on psychological, emotional and social levels.
\end{abstract}

\section{Introduction}

After three decades, the development of Erasmus programmes and student mobilities within the European context of higher education confronts language education with a challenge: that of taking stock and transforming the experience of the journey lived by international students as a leverage for the development of their plurilingual, inter- and pluri-cultural competences. A few scholars have risen to this challenge, integrating the journey (to one or many destinations, short- of long-duration, sometimes intermittent) into formative apparatuses in languages and cultures (Anquetil \& Molinié, 2008, Pungier, 2009, Gohard-Radenkovic, 2015, Molinié, 2015). In this article, we would like question the role that visual narratives can play in transforming the language classroom into a resonance box of what the french philosopher Serres (1997) has referred to with the term random: the journey that has a goal but that unfolds a little by chance. Indeed, we have dedicated a part of our lives as researchers to valuing this phenomenological and aesthetic experience around international students coming 
from different foreign universities, on an academic sojourn in France. First it was videoletters (Maurice \& Molinié, 1994) and then the dramatization of life stories (Liberman \& Molinié, 1998) that led us to progress in this direction, up to the creation of a project in CD ROM, called the travel-knowledge ${ }^{l}$, conceived with Paganini and Zarate at CREDIF, at the Ecole Normale Supérieure of Fontenay Saint Cloud (Molinié: 2000). It is thus with simple drawings that we have chosen to work with international students during their academic stay at the university of Cergy-Pontoise since 2005. This contribution is organized in two parts: we shall first look at our theoretical framework, built on the crossroads of artistic and scientific practices in the social sciences. We shall then study a corpus of drawings produced in 20052006 and see how the graphic representations of "paths and projects of international mobility" produce a shared knowledge on the place of international mobilities in plurilingual trajectories and students' future projects.

\section{Background and theoretical starting points}

From early on, two questions were clear to us in our career as researcher and teacher of French as Foreign Language, teaching our own tongue (at the Université Charles de GaulleLille 3; in two French as Foreign Language programmes of the University of Chicago in France, the University of Berkeley in Paris, at the dept. FFL Communication of the Université de Paris 8 , etc.) to foreign students in international mobility. Firstly, how can bi/plurilingual students represent they international mobility experience visually? Secondly, how does this representation allow them to reflect on and understand the formative and existential impact of their mobilities, in order to pilot the experience instead of undergoing it?

\section{Brief genesis of a research on visual narratives in university mobility}

These questions pertain to different areas. The first is certain artistic practices such as the cinema, theatre or even drawing. The second is the social sciences, principally sociology and the sciences of education. To answer these two questions, we had to get training in these subjects. But it was equally necessary to invent a method that would allow the students (authors and co-interpreters of their own works) and the teacher-researcher, animator of the 
apparatus, to co-construct the meaning of the drawn works. A meaning respectful of individual paths while allowing every one to access a socio-historical inter-comprehension of this human condition: that of being plurilingual students, in international mobility, actors of their own study- and life-choices.

To animate those groups, our encounter with clinical sociology was determinant. Settled within the epistemology of the comprehensive current, following the lines of the work of Weber, Simmel (in sociology) and Dilthey (known for his focus on subjects' empirical psychology of the lived), clinical sociology attempts to take stock of the individual in their singularity and their historicity. It is defined more by its approach than by the objects it attaches itself to, following an anthropological project: that of unravelling the complex knots made up of social determinism and psychic determinism in the behaviour of individuals and groups, as well as in the representations of such behaviour (Gaulejac, 2009, 2013). Vincent de Gaulejac, professor of sociology at the Université Paris 7 Diderot, is the main founder of this sociological current in France, which he proposes from the 90-2000's within the International Institute of clinical sociology (IISC) and later the International Network of clinical sociology. One of the originalities of these research groups in social sciences was they included the use of drawings in the sociological exploration of lifestories. We participated in these training session (in Paris, from 1994 to 1999) and there experienced the personal implication required for drawing and then the reflexive distance the animator invites participants to take once the moment comes to explicit and interpret those drawings within the group, from a sociological perspective. From 1999 to 2001, we received training on the animation of these workshops, and learned to create instructions adapted to our research objectives. Consequently, we created our own workshop at the IISC, called "Cultural trajectory: identity continuity and rupture", in 2000 and 2001, participated by language teachers, social workers, young researchers and social science students come to train in clinical sociology. We proposed to the participants two instructions: "The drawing of my cultural identity today" and "Represent your cultural trajectory in space and time from 2 generations ago". This workshop was the laboratory where we practice and got participants to practice drawing, while reflecting on this method of creation and its possible applications in language pedagogy and in the filed of plurilingual and intercultural education.

\section{First methodological elements}


In the table below, we have synthesised the main results from this action-training experience with our colleagues at the IISC.

Result $\mathrm{n}^{\circ}$ 1: adult drawing is light and thus immediately "usable" in a group. Indeed, making drawings allows draws to construct symbols and visual concepts: a veritable subjective lexicon, see, watched and interpreted for a given time, within the group.

Result $n^{\circ} 2$ : the practice of adult drawing present a strong relational interest: engaged in co-interpretation dynamics, the drawing subjects are stimulated to interact and exchange around their drawing

Result $\mathrm{n}^{\circ} 3$ : Methodologically, the researcher plays a key role:

- A) the drawing instructions they propose are deeply pondered: they should afford participants at once the possibility of becoming implicated (in the drawing) and becoming distanced from it (in the explanation presented to the group).

- B) the animator /researcher should place themselves at the meeting point participant with instruction (rather than identify with the problematic posed by the instruction). It is convenient to think up:

- a) a first instruction to allow a global exploration of the issues lying between the participant's own problematic and the problematic of the workshop (or course) and

- $\quad$ b) a second instruction, more analytical, to allow each person to enter into the detail of the represented situation.

- C) The animator/ researcher should be position as a guarantor of the interpretative framework rather than as a motor of the interpretations. They regulate the exchanges to avoid intrusive interpretations and to remind participants of the deontological rules agreed upon with the group: respect, kindness and non-judgement.

- D) The animator/ researcher should allow meaning to circulate between social facts and feelings, they should endeavour that social objectivity and participant's subjectivity meet the latter may construct the socioexistential meaning (and not just psychological) of the events of facts represented.

Table 1: Methodology of adult group drawing 
After becoming a full-time teacher at the Université de Cergy-Pontoise in 2002 we created a training course in French as foreign language didactics, as well as a Language Centre for students in international mobility. In those capacities, we could put into practice these keys principles: language training of international students, training of language teachers. In 20062008, we gathered specialist researchers in children's plurilingual education (De Dominicis, Perregaux, Clerc, Leconte, Castellotti \& Moore), who also gave importance to accompanying the dynamics of acculturation and pluralistic identity construction, through the use of drawing, in allophonic groups. The publication of these works in 2006 (Molinié, ed, 2006a \& 2006b) and 2009 (Molinié, ed, 2009) culminated in a first definition of the methodology of narrative drawing (in allophonic groups of children and adult speakers) in the glossary of the Guide for the research in language and culture didactics:

\footnotetext{
"Reflective drawing is an apparatus comprising the transmission of an instruction, the making of a drawing (by a child, a teenager or an adult), and an exploratory discussion of the drawing (between the drawer and the practitioner/researcher or between peers). This methodology: 1) makes visible and acknowledges sociolinguistic determinants and their movement in the environment in which the player lives; 2) leads to processes of verbalization, sharing and awareness-raising of these patterns and determinants; 3 ) facilitate re-mediation and the production of new representations; 4) increases social mobility as an open, dynamic, complex, unstable and unpredictable process" (Molinié, 2015: 450).
}

The main objective of the present study is to deepen and complete that first definition.

\section{Research context and methodology}

The drawings we shall present are part of a corpus collected in 2005-2006 from international students, while teaching french language at the Centre International de Langue Française et Action Culturelle (CILFAC - Centre for French Language and Cultural Action) of the Université de Cergy-Pontoise (UCP). We created CILFAC in 2002 as a response to the training needs in French language and culture of foreign students (in a context of exchanges with Europe, Asia and Africa) come to stay at the university to study science and engineering, 
languages, law, literature and economy (in descending order). As director of the CILFAC, teacher and researcher at the CRTF laboratory (Centre for research Texts and Francophonie) of the UCP, our objective was to start a situational action-research (Macaire, 2011) in order to experiment with the notion of international mobility in FFL teaching in university context, and to incite international students of the CILFAC to become aware of the personal and professional gains of these mobilities, through drawing.

\section{Data collection and analysis procedures}

Taking the elements proposed by Macaire (2011: 115-125), we indicate in the table below the objectives, consequences and concrete modalities of this situational action-research.

\begin{tabular}{|c|c|}
\hline $\begin{array}{l}\text { SITUATIONAL ACTION-RESEARCH (SAR) } \\
\text { (Macaire, 2011: 115-117) }\end{array}$ & Our SAR apparatus \\
\hline $\begin{array}{l}\text { Command } \\
\text { Problematising a context }\end{array}$ & $\begin{array}{l}\text { 1- Problematising the notion of international mobility in } \\
\text { FFL teaching in a university context } \\
\text { 2- Inviting CILFAC's international students to become } \\
\text { aware of the personal and professional gains of these } \\
\text { mobilities, through drawing. }\end{array}$ \\
\hline Starting-off: Provoking a situation & $\begin{array}{l}\text { Creating a free EU "Paths and projects of international } \\
\text { mobility" validated by the Council for Training and } \\
\text { stUdent Life, open to inbound (Erasmus) and outbound } \\
\text { (Erasmus, Crepuc, etc.) mobility students. The drawings } \\
\text { are executed within this framework: a } 24 \text { hours course in } \\
12 \text { weeks. Most are students enrolled at the UCP, of levels } \\
\text { B1, B2 and C1. }\end{array}$ \\
\hline $\begin{array}{l}\text { Type of position - relations } \\
\text { Implicated position, horizontal and egalitarian } \\
\text { relations: the researcher initiates a democratic } \\
\text { organisation of the work situation. It is the actors } \\
\text { collective work that defines the situation. }\end{array}$ & $\begin{array}{l}\text { Creating an ethics code allowing each person to become } \\
\text { implicated and to reflect on their own "international } \\
\text { mobility" (and that of their peers) in an open way, without } \\
\text { judgement or evaluation. }\end{array}$ \\
\hline $\begin{array}{l}\text { Type of knowledge production } \\
\text { Knowledge by a series of individual and social } \\
\text { transformations, production in real time: the } \\
\text { knowledge produced in situation shows elements } \\
\text { impossible to obtain by classical means. }\end{array}$ & $\begin{array}{l}\text { Knowledge of the forms and gains of mobility for each is } \\
\text { elaborated in - and thanks to - the work initiated in the } \\
\text { course. }\end{array}$ \\
\hline $\begin{array}{l}\text { Production utensils: qualitative and interactive (self- } \\
\text { learning, group dynamic, cooperative workshop). }\end{array}$ & $\begin{array}{l}\text { Reflexive drawings, texts, qualitative interviews in pairs } \\
\text { and groups, mutualisation of the productions within the }\end{array}$ \\
\hline
\end{tabular}




\begin{tabular}{|c|c|}
\hline & group. \\
\hline $\begin{array}{l}\text { Efficiency and spreading of knowledge produced: } \\
\text { knowledge is a direct agent of transformation; it is } \\
\text { spread by meetings in workshops, public } \\
\text { interventions and self-learning courses. }\end{array}$ & $\begin{array}{l}\text { Knowledge co-produced is an agent of transformation: a) } \\
\text { for participants, b) for the CILFAC, c) for the didactics } \\
\text { community (through the production of research literature } \\
\text { on reflexive drawing from } 2009 \text { onwards). }\end{array}$ \\
\hline $\begin{array}{l}\text { Relation to time and analysis of knowledge: it is a } \\
\text { work in progress, collectively self-assessed and self- } \\
\text { formed; work on social representations and the } \\
\text { principle of constructing reality, collecting feedback } \\
\text { (analysing response of participants on documents } \\
\text { produced). }\end{array}$ & $\begin{array}{l}\text { The transformative aim of the course is supported on all } \\
\text { these dimensions. }\end{array}$ \\
\hline $\begin{array}{l}\text { Real transformations: participants are the authors } \\
\text { and owners of their productions and the meaning } \\
\text { they give to them. They agree for the researcher to } \\
\text { show the works co-produced in the workshop. }\end{array}$ & $\begin{array}{l}\text { Participants give their authorisation for us to publish their } \\
\text { drawings and productions. }\end{array}$ \\
\hline $\begin{array}{l}\text { Epistemological approach to a social situation: } \\
\text { Systemic: complexity, the situation is a system of } \\
\text { interactions and events. } \\
\text { Micro-sociological: the situation is a tool to analyse } \\
\text { the whole society. }\end{array}$ & $\begin{array}{l}\text { Drawn representation of each individual university } \\
\text { sojourn becomes a tool to analyse the system of student } \\
\text { mobility in a continuum between the micro- and macro- } \\
\text { sociological levels. }\end{array}$ \\
\hline $\begin{array}{l}\text { Objectivity and scientificity: no preliminary } \\
\text { hypotheses of methodologies, back-and-forth } \\
\text { between implication and distancing, the researcher's } \\
\text { influence is a part of the research. Objectivation } \\
\text { through comparison in space and in time. }\end{array}$ & $\begin{array}{l}\text { Comparison with other works allows access to the } \\
\text { development of a longitudinal understanding of the work. }\end{array}$ \\
\hline
\end{tabular}

Table 2: The place of visual narrations in a SAR

\section{Typical unfolding of the course}

As indicated above, the drawings were produced in 2005-2006, in a course called "Paths and projects of international mobility". The course unfolded in the following fashion. The course opens with a collective brainstorming proposed by the teacher on the notion of "mobility". Asking students for their ideas allows each participant to create bridges between the problematic of the course and experience lived personally on the theme. The brainstorming activity is fundamental: founded on the free association of ideas, the possibility of being inspired by what others say, the prohibition of self-censorship or censoring others, it allows 
for a defusion of any attempt to set up a hierarchy between mobilities perceived as legitimate, and mobility outside of exchanges, outside of conventions or partnerships, perceived as less valued and not very enriching. This collective activity introduces in the group an anthropological and political discussion on the role of educational mobility not only in the development of planetary human exchange, but also in the development of our humanity and our humanism. The Joint declaration of the European Ministers of Education of 19 June 1999, or Bologna Declaration, followed by a short philosophical essay by M. Serres are brought in to contextualize and historicize this initial reflection.

The visual narration activity is proposed in a second moment, from the instruction: "Draw your path and project of international mobility. Explain the drawing". Once the drawings and finished, students gather in groups of three to explain their drawing to the other members of the sub-group. In a third moment, other activities are proposed that allow interaction to be enriched, favouring a living appropriation of cultural and linguistic knowledge, as well as the development of comunicational and relational competences within the group, constantly connected to each person's historicity. These dialogical moments lead to the individual writing of an autobiographical essay. Finally, participants reflexively and critically appropriate two of the tools put forward by the Council of Europe to furnish their European mobilities: the European portfolio of languages for higher education (edited by the European Confederation of Higher Education Language Centres) and the Europass CV, the objectives of which have been presented to them by the International Relations department.

\section{Presentation of the corpus and findings}

Some thirty drawings were made by students in 2005-2006 in response to our instruction "Draw your path and project of international mobility. Explain the drawing". Most were entrusted to us in the perspective of publishing the results of this action-research. They were in two groups: two thirds of them show the need to occupy a place in the world; a third expresses the need to be in dynamic relation with the world. Analysis of these drawings was initiated in 2005 with a $\mathrm{PhD}$ student at the CRTF (Marie Blancart, PhD in compared literature) and Aline Bergé, teacher-researcher at the Department of French as a Foreign Language at the Université Sorbonne-Nouvelle Paris 3, also a specialist in compared literature. We followed our analysis with the contributors from the two research seminars called "Drawing and destination: from lines to traces" culminating in the publishing of our collective work in 2009. The analysis underlines the way the drawings' authors: 
- interpret the retrospective aim of the instruction through the concept of path, and represent mobility through a pre-existing reality and a history of the drawing subject;

- interpret the projective aim of the instruction through the notion of project and represent mobility in relation with a plurilingual and intercultural experience which is in construction and in transit;

- represents the actor's reflexivity.

\section{Drawings expressing the need of having a place in the world}

The 12 drawings presented beneath are a part of this last category representing student mobility as an experience taking place in a pre-existing reality, a series of choices, a lebensweg or a programme. The student highlights the importance of situating their experience of mobility in an ascending continuum with their first socialisations, without rupture between the stages of sociality, marked by coherent filiations and affiliations. The intercultural and plurilingual experience generally associated to international journeys is more or less mentioned in these drawings. Once it is, it does not necessarily introduce the possibility of further choices for the actor (creating a rupture with what precedes it). In effect, the reflexivity acquired in mobility is seen as merely adding to the social actor's level of disquiet toward their own future. In this category, symbols represent the fulfillment of destiny, the meaning of which the subject does not question. On the other hand, the stage of postmobility, symbolised by a question mark, is represented as an uncertainty. We subdivide this first family of drawings into three sub-groups.

The first sub-group, figures of social or symbolic ascension, includes all the tubular, circular or spiralling figures; drawings of open and closed pyramids; also organizational charts, ascending steps, the life street, as a plane, a comic strip, or a puzzle. These images have several points in common. They present a base or departure point that refers strongly to the ensemble of cultural and symbolic capital acquired throughout the life of the young student. Their summit or end point is university and France. The paths represented are marked by a series of structural events such as:

- education, organized leisure on the family level, inhabited environments (house, countryside, sun, flours, stars...) and siblings,

- the academic career, journeys abroad (United States, England, France, Saudi-Arabia) and acquired diplomas, 
- social engagement (local politics, the church, the Red Cross)

- juvenile sociabilities (parties),

- arts (piano) and sports (water polo, swimming, judo),

- selective tests (high school diploma, sports competitions),

- the romantic affair (sweethearts),

- autonomy acquired at university («away from home») or through a driving license.

This succession of events and formative situations closes with a last stage, identified and named.

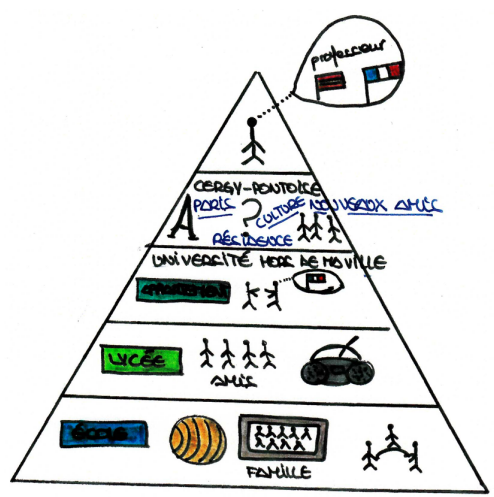

I.1.1. Having a place in the world? Noelia's drawing

Such is the case of Noelia's drawing, where the tip closes over the figure of a french teacher in Spain.

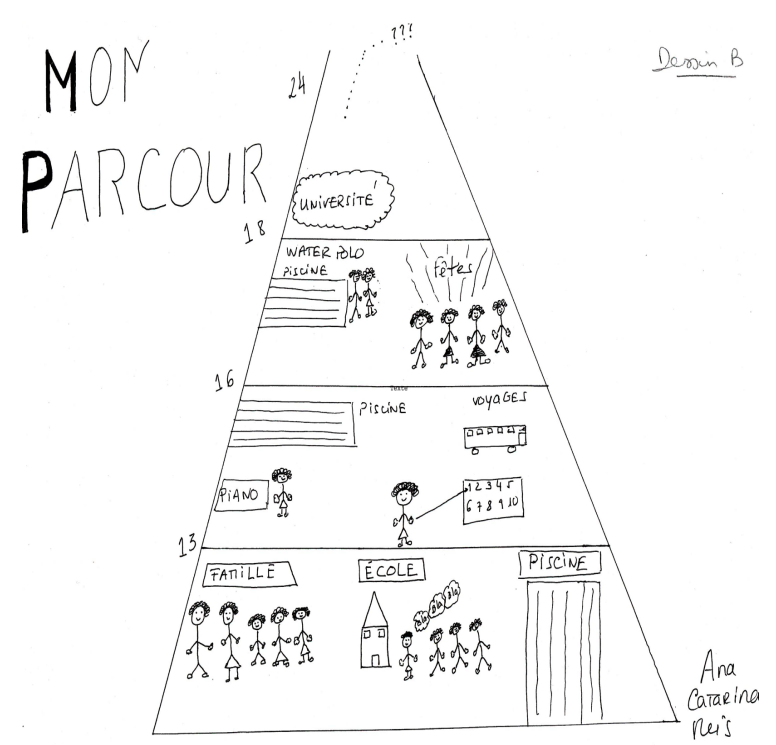

I.1.2. Having a place in the world? Ana-Caterina's drawing 
Much more frequently, the drawing opens out into one (or more) question mark(s). Such is the case with Ana-Caterina's pyramid top, bearing the word "university", and opening onto 12 dots and 3 question marks.

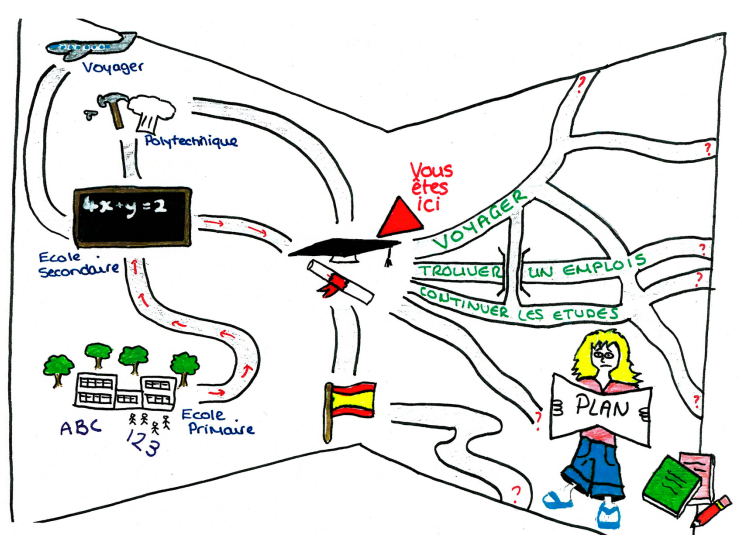

I.1.3.Having a place in the world? Brigitte's drawing

Brigitte draws a long-haired girl wearing trousers and a perplexed expression, with a sign saying "map" on her chest. At her feet are books. To her left, the ensemble of her path (from school to Polytechnic) and her acquisitions (diplomas). Above her, a red triangle indicating You are here. Before her, are three paths, in interrogation: travel? find a job? continue studying?

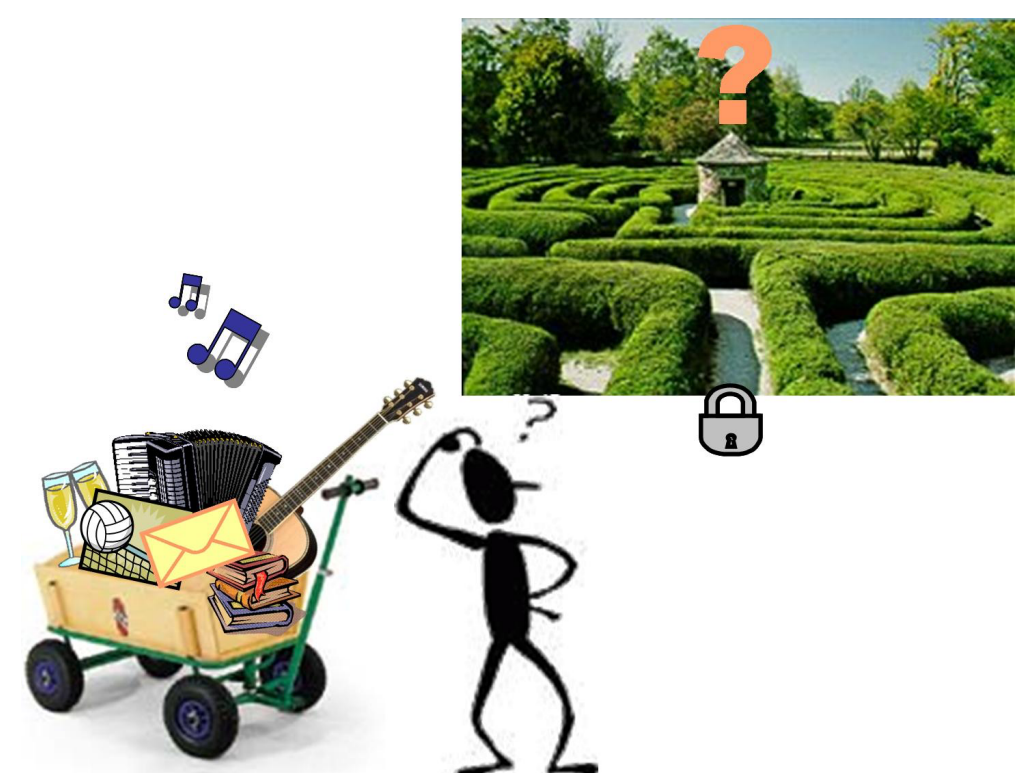

I.1.4. Having a place in the world? Julia's drawing

The small character created by Julia also shows great perplexity: it scratches its head while, to its left, is a wheelbarrow full of baggage (many books, musical instruments, etc.). In front of 
him a labyrinthine garden with a central shed with a question mark hanging over it (showing Julia's drawing was not made in class but with electronic tools). Here, still, the cultural baggage acquired is not enough to suppress the interrogations concerning the future.

In synthesis, we can say these drawings give priority to the path and the participant's training, showing strong coherence in the construction of the actor's social and cultural identity. The search for continuity is more relevant than the international dimension: this dimension is in effect little or not represented.

A second sub-group, mastering an opening to the world, includes stylized terrestrial globes, intersections, crossroads and labyrinths and brings to the fore the effort deployed by the student to give a global meaning to their path, and particularly to this mobility project. These drawings interpret the instruction more in its projective dimension than its retrospective one. The effort of mastering the dynamics of mobility seems to leave less space for doubt or disquiet towards the future.

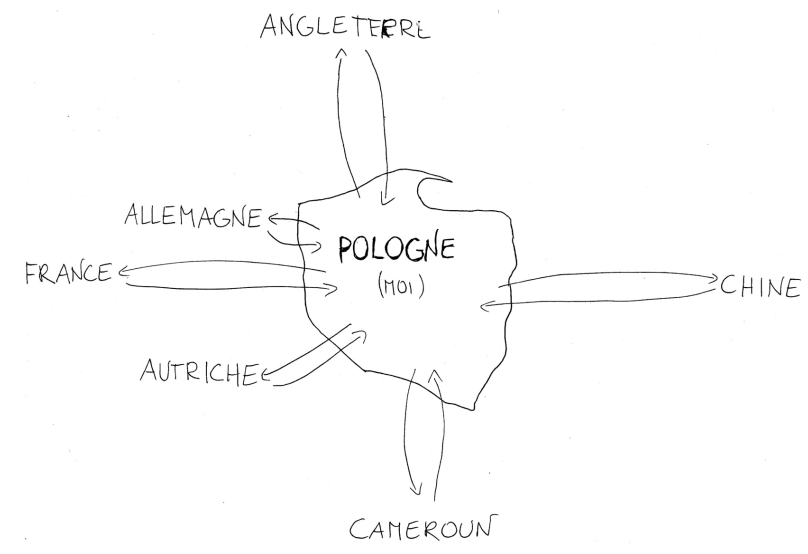

\subsubsection{Having a place in the world? Agniseska's drawing}

Thus, Agniseska's drawing places a vaguely geometrical figure «Poland (me)» at the centre of a series of back-and-forths between: to the left, the word France; to the right, the word China; above, Germany and England; below, Austria and Cameroon. Double-arrows indicate a pendular mobility between these destinations and the centre: Poland (Me). No indication is given concerning the cultures and languages associated to these mobilities. 

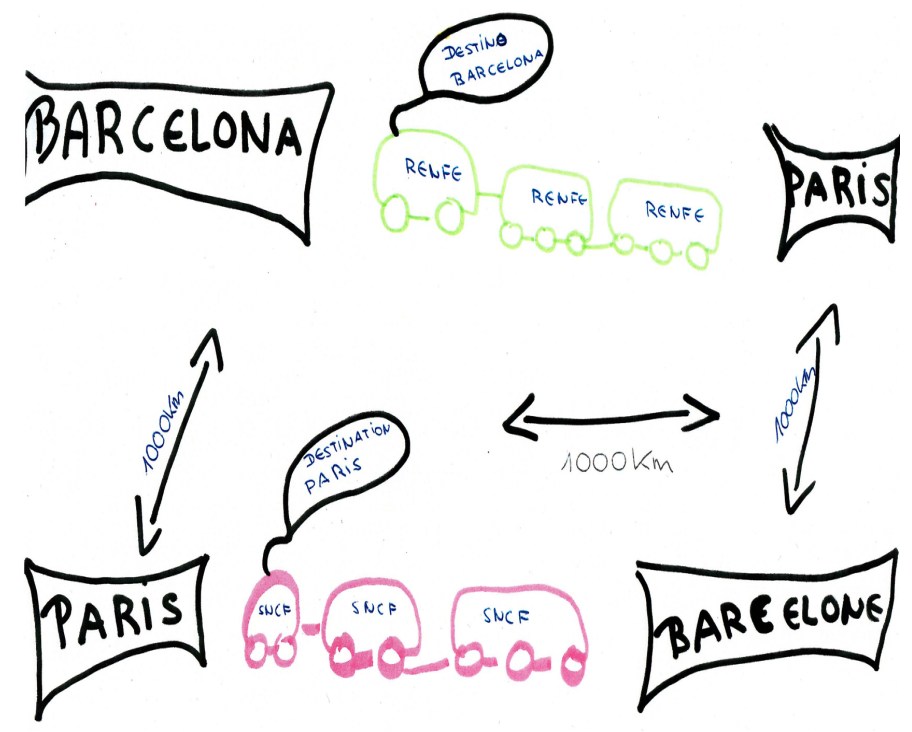

\section{I.2.6. Having a place in the world? Maria's drawing}

A pendular mobility for Maria also, who represents a series of back and forths between Barcelona and Paris through the French national railroad (SNCF, from Paris) and Spanish national railroad (RENFE, from Barcelona).

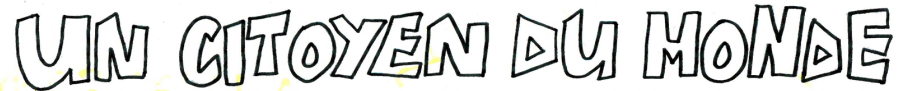

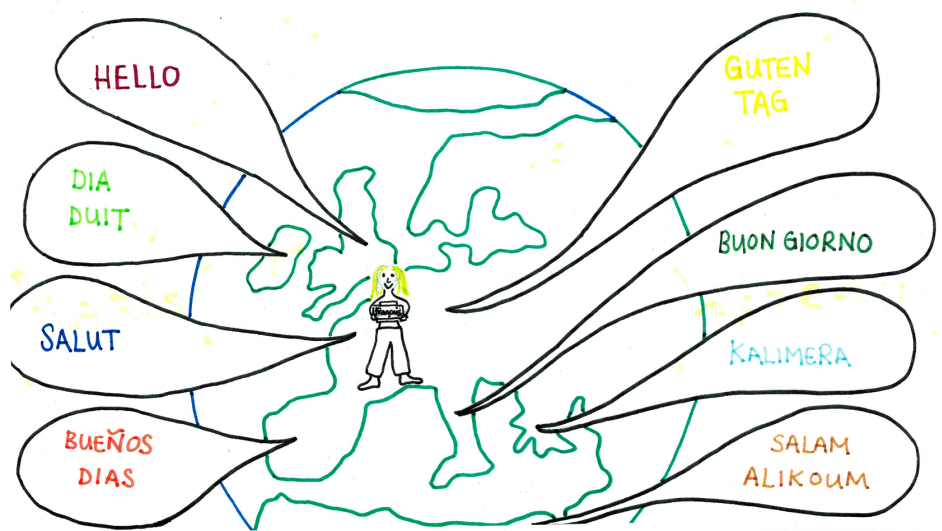

I.2.7. Having a place in the world? Jane's drawing

Jane pictures a smiling girl, wearing trousers, holding a small sign French to her chest and camped at the middle of a world map (where different countries have been traced). She is haloed by 8 big bubbles which contain the word Helloin different languages. The title of her drawing is "A citizen of the world" in capital letters. 


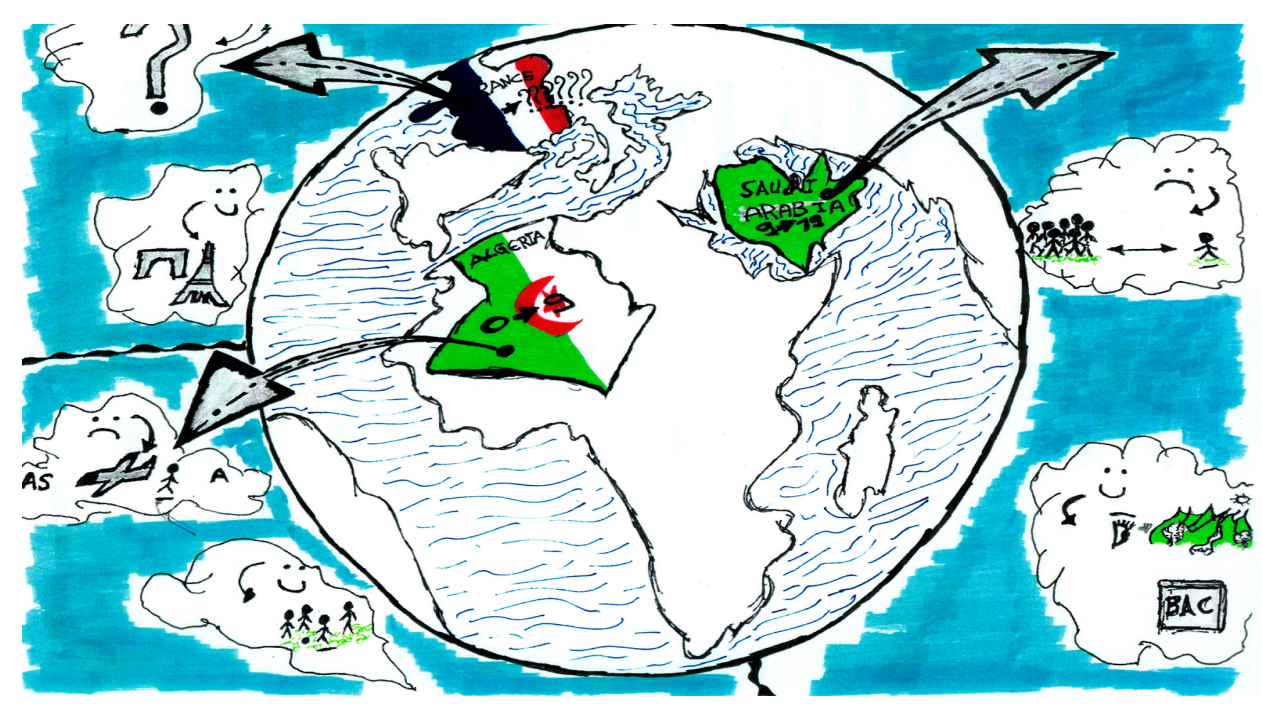

I.2.8. Having a place in the world? Samir's drawing

Samir's world map has two specificities: it is surrounded by the blue of the oceans and it has two big arrows going through which represent aerial routes departing from 2 countries: Algeria (where Samir indicates having spent the first 9 years of his life) to Saudi Arabia (where he was schooled from age 9 to 19, until finishing high school), and from France to an unknown destination (pictured as 6 question marks).

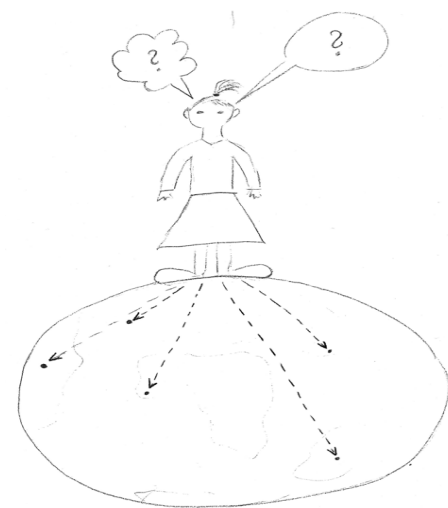

I.2.9. Having a place in the world? Katja's drawing

Finally, Katia draws a girl in a skirt, sure on her two legs, with thick shoes on top of a terrestrial globe drawn as a simple circle, with 5 possible paths under her feet and two bubbles above her head with question marks. Katia explains her overbearing position with the following words:

"The fact that I am above doesn't mean I am the queen of the earth! It means I have a distance towards other countries and my homeland. I can see differently and discover other countries. I represent a person with the nose, the mouth, the ears: its important to have senses. I can see, I can hear, I can smell, I can touch and this makes my discovery of the world easier. I drew the feet and shoes very big to go always farther, perhaps 
beyond my country, my mentality, to cut back on bad habits, everything that stops me from getting to know others".

To synthesize, in this second ensemble the path is international, highlighting displacement to the origin; the possibility of pluralizing or mixing of identity is evoked, even valued if the reference to a place of origin is important. In this group, the relationship with the international dimension is dynamic, open and in continuity with national belonging. Katia highlights this in explaining that:

"the meaning of my drawing is that it presents my international mobility. If I am autonomous enough I can go where I want. A journey in its real sense (coming here) but also the intellectual journey I've been on since my childhood to discover otherness and enrich myself. The globe is circular. As we know, history, the world presents a circularity, plus the circular movement of my life because when I was a child I would imagine journeys, other cultures. Now I am here, repeating this feat from childhood. The dream of knowing different things".

We identified a third sub-group, unopened paths. Here we find two anonymous corridors (or tunnels), with doors (12 in Wilhelm's empty corridor, 10 in Marta's), in which a lone character (a girl with her back to the viewer, at the start of Marta's corridor) is crowned by 4 question marks. Toni presents a series of rectangles using the colour codes of flags (black, yellow, blue, white, red) but reversing them or making up new ones (checker patterns or black stars). The weight of the decisions that lie ahead is what characterises this group.

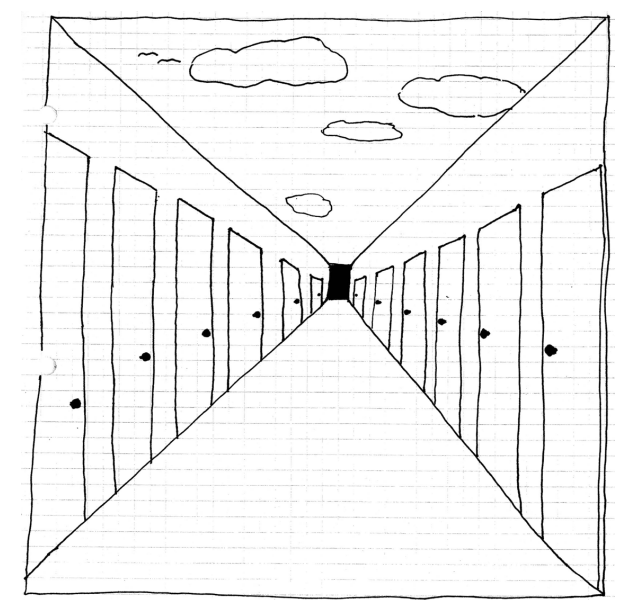

I.3.10. Having a place in the world? Wilhelm's drawing

Thus Wilhelm presents his drawing, explaining he is inspired by the idea of a path being made of "many decisions" and that the corridor symbolises the current period of his life, which follows a previous corridor. The 12 doors, he says, have two meanings: they are possible decisions or possibilities found in his life, as opposed to the previous period in his life in which "there was only one door". The end of the perspective is painted black because 
"I don't know what will happen to me if I go to the end". Invited to proceed, he specifies that the doors are possibilities concerning people one might meet and places one will visit. $\mathrm{He}$ chose this metaphor because doors "are similar to life in the sense that we have an idea of what lies behind a door but we can never know if we don't open it".

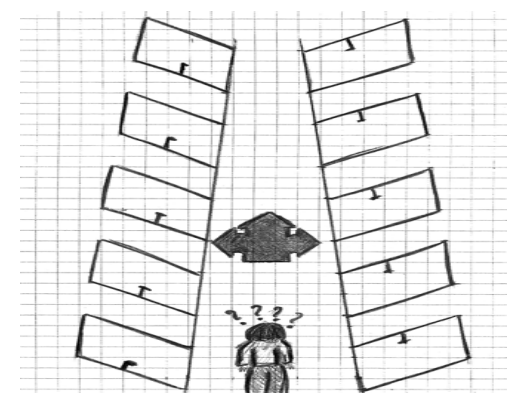

I-3-11: Having a place in the world? Marta's drawing

Equally for Marta: "this corridor is a metaphor of my life where the door are the paths. To take one path, is to acquire a new experience, its risky". She recognizes that many factors influence us but affirms that "it is we who decide how we want to live" and adds:

"the most important decision in my life was coming here. The other important decisions are the question marks. One of them will be to stay here and finish my studies in France or go back to Poland. This decision means opening a door and going there instead of staying at this point. It is also possible to live our life without opening doors, it's a bit boring because that means we go to the end of the corridor but we don't do anything new. Me, I want to open many doors".

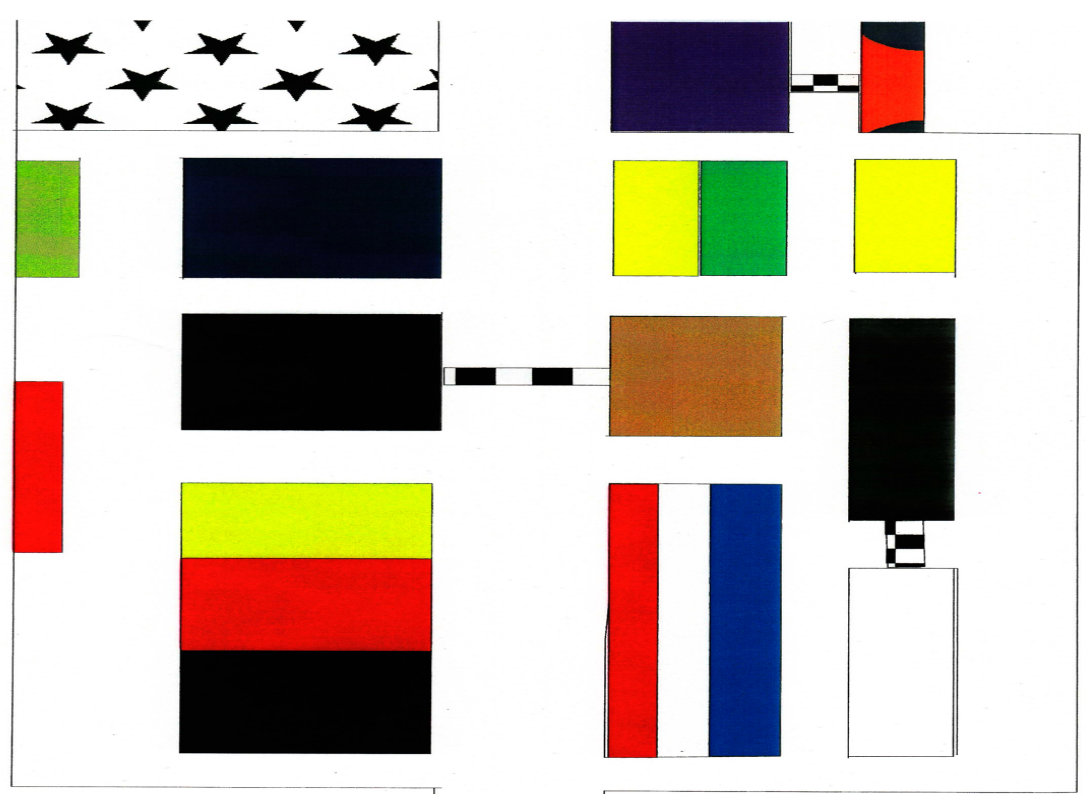

I-3-12: Having a place in the world? Toni's drawing 
Finally, Toni explains that his drawing "is an abstract image of his path. There is no chronological sense but the meaning of the relations between things: its the map of a city, with the buildings, the blocks, the blocked streets, the dead-ends which are obstacles, difficulties to reach a goal. The buildings have colours of flags which are also fundamental pillars of a nation". He reminds us he was born in the German Democratic Republic in 1984 and that "until the age of 6 it was a journey without journeying: I just collected the different colours of flags". But, after the fall of the wall "we visited different European countries because we could travel". He is critical of the reunification: "everything is still very closed. For me in 1989 it was not a reunion (rather a conquest or annexation) because the GFR put its hat over the GDR (übernehmen)". He is also critical of the way his coming to France has unfolded, deploring the "obstacles, the organisation of this year, the bureaucracy, the money, the social obstacles" to his stay. He "must then find another way, there are always alternatives possible". He ends by explaining that living in France "this has a special role in relation to my future. I want to make usage (anwendung) of my knowledge acquired here in law to help my country of origin. Civil rights must be Europeanised, because without this we shall be lost in 20 years time".

This last sub-group of drawings highlights two elements. First, the decision to come study at university in France is, for Marta and her colleagues, one of the most important decisions of their life. Second, the impact of this decision on the rest of their lives is major. Which is why producing the drawing sparks an ethical discussion between them on questions of loyalty and responsibility to their three countries: Austria, Poland, ex-DRA. Between determinism and freedom, Marta sticks up for the possibility of choosing in order to, at the end of one's life, take responsibility for those choices: to have opened all the doors she wanted to. Wilhelm draws the sky "with small, non menacing clouds" above this "sombre and impersonal building" and declares "to be at ease with my decisions" in this tubular space, but with an open sky. Toni situates his stay with the perspective of putting the competences he is acquiring in law in the service of all Europeans from East to West.

\section{Drawings that express capacity to be in relation with the world}

Drawings classified under this category are particularly expressive. They represent student mobility as a creative experience of change: it opens a crack, creates an existential dynamic towards a mutation of the subject. 


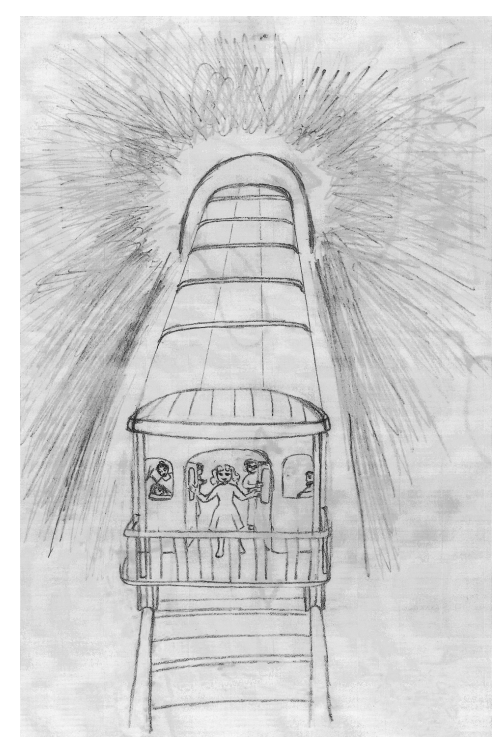

II-1-1. Being in relation with the world. Ana's drawing.

The image of the passage (Ana, at the head of a locomotive exiting a tunnel) and of the turning point is there, in between the lines. When it is represented, the plurilingual and intercultural experience is a key factor in this dynamic, even if it can be a cause of disquiet as change operates and obstacles (real and imagined; objective and subjective) are encountered. Aimless wandering can happen from not elaborating on a purpose with respect to the experience of mobility. Ultimately, reflexivity acquired in mobility is not connected to anxiety towards the future.

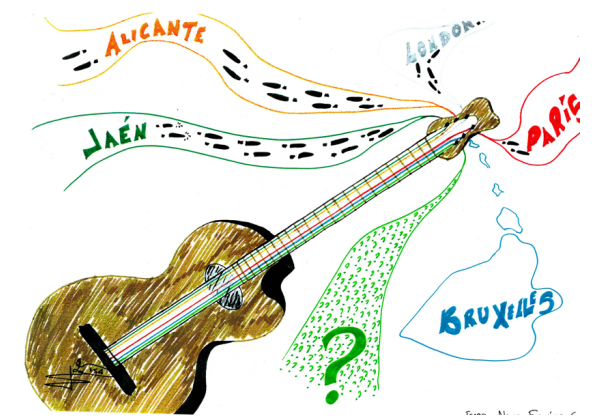

II-1.2. Being in relation with the world. Isabel's drawing.

In this family of drawings, we find a path in the shape of Isabel's guitar (who, from Alicante, to Jaen, Paris or Brussels, makes her possible destinations into music, replacing the notes with the shape of her footsteps); Rico's gushing champagne bottle, but also mountains (in Laurence or Catia's drawings), who draw their character bravely climbing and that represent the real and imaginary obstacles. Once overcome, these tests make an individual more autonomous. As Ana explains to the students of the group:

"It's a train in a tunnel towards the light: the tunnel, its passing from one state to another, its a way of passing from one world to another. I see myself travelling with my parents, then alone. Each time I go, I go to another world, a new world. The train 
is the first mode of transport I took all alone: in an adventure. I am attached to them since childhood, it has always been the way to fulfill my dreams, it was the way my story characters (that I made up) would travel, with wheels of smoke, its the dream."

The world here, then, can be either a challenge, or a point of support (fulcrum) or a mere surrounding, an entity to be embraced, mastered (in the sense one masters a skill), which an actor can confront, but which will not be crushed.

To conclude on these two groups of drawings (having a place in the world and being in relation with the world), let us come back to the double dimension aesthetic and phenomenological of the journey or random. As mentioned before, according to Serres, this term attempts to "describe the conditions of perception once the body is at its closest to the perceived". But in what ways do the drawings of the students show their perceptions of the journey through an individual aesthetic? Most of the drawings shown above represent the journey in aesthetic that represents the polyphony (Isabel), polyglossy (Jane) and other forms of plurality: cities (Maria), destinations (Samir), flags (Toni), possible choices (Wilhelm, Marta), etc... The nuance between these drawings would thus be less at the level of an aesthetic of plurality than a representation of the subjective relationship the individual expresses towards this plurality. We have already seen how Ana represents and tells of her capacity to use the train to go beyond the world. Let us now take a look at how Geneviève situates her international journey in the story she tells 12 years after she drew her drawing.

\section{The drawing as narration and as projection}

In 2005, Geneviève had just arrived in France, where she would become a student at UCP where she did her first year of bilingual programme (French-English) in Technical Sciences. Enrolled in her first year in maths, physics and IT, she would quickly re-orient towards physics, chemistry and the earth sciences.

She participated actively in the discussions around her colleagues drawings. If her own drawing was the object of an oral presentation to the group, the record of this explanation was unfortunately not correctly archived and kept. 


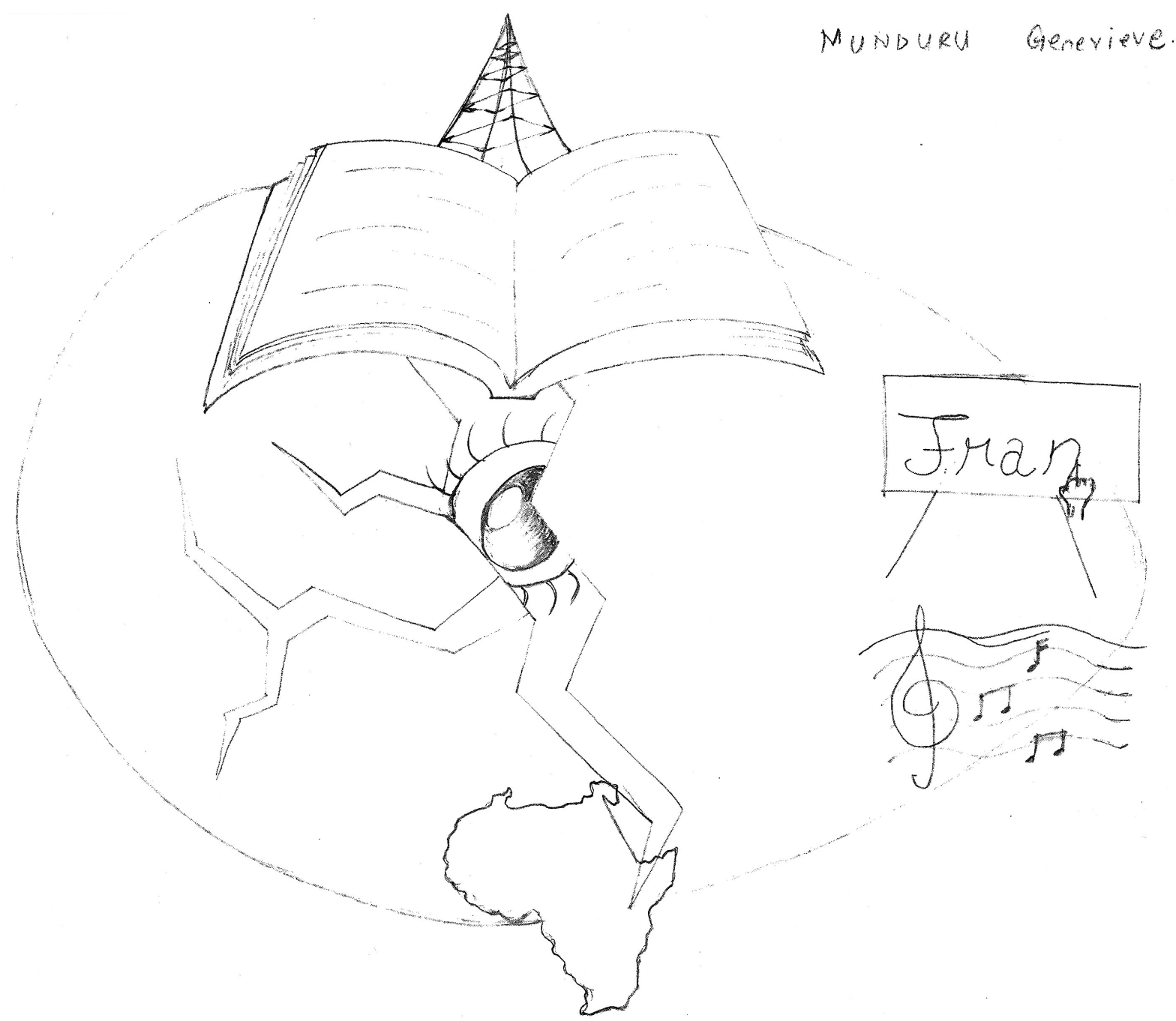

II-1.3. Being in relation with the world. Geneviève's drawing.

Never having forgotten its expressive and narrative force, we vividly wished to report on it for this article. Which is why we searched and successfully contacted Geneviève through a social network. We asked some questions by message, to which she promptly replied in French. We bring here the key points of that research correspondence which took place in April 2017, over a period of 9 days.

First of all we asked if she would explain what this drawing represented in 2005, at the moment she drew it and what she had expressed back then. This was her response:

"This drawing is composed of the following elements: an egg, the shell is cracked in the middle with an eye in the interior. A drawing of the map of the African continent. A few musical notes. A board, some chalk and the writing "Fran". An open book. A rig (drilling equipment)".

She then comments on the musical notes and the board on the right-hand side of the drawing. Her mother wrote songs and taught music and G. had always loved music and sang at school. In the Ugandan school context, high school finishes in December, and students must then wait 8 months before they can start their studies at university. "It is thus important to find a 
pastime". This is how G. helped the french teachers at her old school, by giving language classes to students from the years 4 to 6 . She then comments on the aspects of the drawing that represent her arrival in France and "her hopes for their future":

"My feeling as a new arrival in a country that was foreign to me was that of a chick trying to leave its egg for the first time. I knew I was in France to study (the book) and I felt at that moment that studying successfully was the only way for a young girl from East Africa (the crack in the shell) to get to work in the oil industry (the rig at the top of the egg). So, my interpretation of my path was related as much to my past as to my future".

Some days later, she adds a remark concerning the Eiffel tower:

"This comes to me bit by bit. So, the crack in the shell starts in Africa and finishes in Paris with the books in the middle representing the reason I had come to Paris. The concept of the rig surprised me in fact because at the time, I had no idea what I wanted to do. I was still in the process of discovering my new environment".

To the question "Could you explain in some lines how you interpret this drawing today?" she answers the following:

"With a lot of hindsight, I interpret this drawing as a prophecy. I was aware of my duty as a student to work and succeed but if someone had told me this drawing will be a reality 5 years later, I don't know how I would have reacted. I left my thoughts, my wishes, my understanding of my duties in a drawing and focused on my studies. Today, I am in my sixth year with O. (a French multinational company) in the post of Research and Training Engineer."

Invited to precise what she means by "prophecy" she writes: "I think that, what was a reflection of my subconscious on my desired future ended up becoming fulfilled. Probably, without noticing it I gave it my all. When we want, we can (smiley sun emoticon)."

This exchange clarifies the formative gains of a visual narrative in an individual's lifetime seen from the long-term: to the articulation between student life and first professional choices. Indded, in this drawing, G. connects three moments of her life: childhood and adolescence In Uganda, the passage to student life in the french unversity environment and a professional future, still blurry at the time of drawing. Two types of acquisitions can be seen: those from her heritage and filiations (as a young ugandan woman, plurilingual, born and socialised in East Africa) and her affiliations (mainly through music, french language, an initiation french teaching in Uganda, enabling the possibility of following studies in a francophone context, in a bilingual degree: french-english). A desired future will progressively take form in the energy sector, leading G. to a diploma in 2010, then a job in the oil business where she is recruited in 2011 and where she practices to this day.

\section{Discussion}


Our study contributes to the recognition of the major role played by the university journey as experience represented and signified, in the formation of an identity of plurilingual subjects in mobility. One of the remarkable aspects of these drawn narrations is that they come to give a materiality to the space-time in which these students produce their identity, open up to otherness and to plural experiences.

University pedagogy issued from this action-research values a culture of views and interpretations, multi-modal processes of co-construction of the meaning of mobilities, with respect (and confrontation) of subjective points of view. Its first aim is to foster an increased inter-subjective awareness of the international mobility experience, thanks to the drawn representation of international mobility paths and projects. At the same time, it aims to develop the performativity of the subject in relation to its deplacement, since it involves acting on one's life via the representation of the self in deplacement. It aims at the development of a humanist comprehension, historicized, of a european and international space of higher education.

This is why this work attempts to avoid the two traps pointed out by Peressini (2015: 7). On the one hand, apprehending actors as "simple executers of economical, social, political and symbolic determinations". And on the other "falling in the subjectivist simplism where everything is reduced to the creation of a world by the atomised, voluntarist actor".

Thus, this study leads us to complete the definition of reflexive drawing presented at the begining of this article, and to characterize the drawings presented above as sociobiographical drawings in which the subject is invited to contextualise their experience, the event or the situation represented, in a social environment and historic epoch. This contextualisation can be effected, either in the drawing itself, or in the phase of verbal explicitation (oral or written) of the said drawing. It leads the author/narrator to operate an articulation between the microsociological level of their practices as actor, and the meso- and macro-sociological levels of their contexts and constraints. This articulation allows each participant to pose the question of the degree of freedom they recognize in themselves and, most of all, to comprehend the conditions of possibility for such freedom. But most of all, this allows for "a back-and-forth between intellectual, theoretical knowledge and sensible knowledge, between reflection and lived-experience" (Hanique, 2009: 33). Finally, these visual narratives enrich the sociobiographical mediations which concern the ensemble of semiotic transactions allowing a subject to live their path as a personal overcoming, a search for congruence between an old and a new perception of the world, between the need to act in situ and the need to project in the future. This double movement of conscientization/agencing allows for internal and 
external identitary negotiations, which are necessary for the subject to live its multilingualism and its mutations.

\section{Bibliography}

Anquetil, M. and Molinié, M. (2008) L'expérience Erasmus au miroir de la réflexivité: penser et construire les acteurs sociaux. In: G. Zarate, D. Lévy, C. Kramsch. Précis du plurilinguisme et du pluriculturalime. p. 83-86. Paris. France: EAC.

Gohard-Radenkovic, A. and Veillette, J. (2015) Nouveaux espaces dans de nouvelles logiques migratoires? Entre mobilités et immobilités des acteurs. Cahiers internationaux de sociolinguistique 2015/2 (8), p.29-46. DOI 10.3917/cisl.1502.0007

Feldhendler, D. (2014) Playback Theatre, théâtre-récit, théâtres en miroirs. VST -Vie sociale et traitements. $1\left(\mathrm{~N}^{\circ} 121\right)$. Toulouse: Erès. 72-78.

Gaulejac, V. de (2009) Qui est «je»? Paris. France: Seuil.

Gaulejac, V. de (2013) La direction de thèse : comment transmettre la clinique ? In V. de Gaulejac, F. Giust-Desprairies, A. Massa (dir.), La recherche clinique en sciences sociales. Toulouse. France: Erès. 313-317.

Hanique, F. (2009), Enjeux théoriques et méthodologiques de la sociologie clinique, Informations sociales, $\mathrm{n}^{\circ} 156$, p. 32-40, http://www.cairn.info/revue-informations-sociales2009-6-page-32.htm

Serres, M. (1997) Nouvelles du monde. Paris: Flammarion

Macaire, D. (2011) « Recherche-action en didactique des langues et des cultures: changer les pratiques et pratiquer le changement ». In M. Molinié (ed.) Démarches Portfolio en didactique des langues et des cultures. Enjeux de formation par la recherche-action. CRTF. Belles-Lettres. Amiens: 113-124.

Maurice, M. and Molinié, M. (1994) De la socialisation à l'échange: la lettre vidéo, un carrefour épistolaire et vidéographique. In C. Alix et G. Bertrand, (eds.) Pour une pédagogie des échanges. Le Français dans le monde Recherches et applications. Paris: Hachette Edicef. 68-70.

Molinié M. and Liberman M. (1998) Trajectoire biographique et espace théâtral. In Le français dans le monde $\mathrm{n}^{\circ}$ 288. Paris: Hachette. 69-72. $\leq$ halshs-01224913 $>$ 
Molinié, M. (2000) Le savoir-voyager: échanges et multimédia. In: D. Groux et N. TutuiauxGuillon, (eds.) Les échanges internationaux et la comparaison en éducation. Pratiques et enjeux. Paris: L'Harmattan. 153-159. <hal-01474609>

Molinié, M. (2006a) Mobilité européenne: en faire le récit, en dessiner les frontières. In S. Galligani, V. Spaëth, F. Yaiche (eds) Contacts des langues et des espaces. Frontières et plurilinguisme. Paris: Synergie France n ${ }^{\circ}$. 226-231.

Molinié, M. (ed) (2006b) Biographie langagière et apprentissage plurilingue. Le français dans le monde. Recherches et applications. France. $\leq$ halshs-01224908 $>$

Molinié, M. (ed.) (2009) Le dessin réflexif: élément d'une herméneutique du sujet plurilingue. Centre de Recherche Textes et Francophonies (CRTF). France. Encrages-Belles Lettres $\leq$ hal-01475642>

Molinié, M. (ed) (2014) (Se) représenter les mobilités: dynamiques plurilingues et relations altéritaires dans les espaces mondialisés. Revue Glottopol 24. http://glottopol.univrouen.fr

Molinié, M. (2015a) (2nd edn). La méthode biographique : de l'écoute de l'apprenant de langues à l'herméneutique du sujet plurilingue. In P. Blanchet et P. Chardenet (eds) Guide pour la recherche en Didactique des langues. Approches contextualisées. AUF-EAC.144154.

Molinié, M. (2015b) Recherche biographique en contexte plurilingue. Cartographie d'un parcours de didacticienne. Actes académiques. Série Langues et perspectives didactiques Paris: Riveneuve.

Pungier, M.-F., (2009) Traces d'expérience de la langue dans des journaux d'étudiants japonais en mobilité ou le récit d'une métamorphose. In A. Gohard-Radenkovic et L. Rachedi, Récits de vie, récits de langues et mobilités. Nouveaux territoires intimes, nouveaux passages vers l'altérité. Coll. Espaces interculturels. Paris. France: L'Harmattan. 51- 73.

Peressini, M. (2015). Préface. Cahiers internationaux de sociolinguistique 2015/2 (8), p.7-17. DOI 10.3917/cisl.1502.0007

End notes

Le savoir-voyager, in the original French. 